Article

\title{
Improving the Early Properties of Treated Soft Kaolin Clay with Palm Oil Fuel Ash and Gypsum
}

\author{
Abdulmajeed Al-hokabi ${ }^{1, *(\mathbb{D}}$, Muzamir Hasan ${ }^{1}\left(\mathbb{D}\right.$, Mugahed Amran ${ }^{2,3}, * \mathbb{C}$, Roman Fediuk $^{4}(\mathbb{D}$, \\ Nikolai Ivanovich Vatin ${ }^{5}$ and Sergey Klyuev ${ }^{6}$
}

1 Department of Civil Engineering, College of Engineering, Universiti Malaysia Pahang, Lebuhraya Tun Razak, Kuantan 26300, Pahang, Malaysia; muzamir@ump.edu.my

2 Department of Civil Engineering, College of Engineering, Prince Sattam Bin Abdulaziz University, Alkharj 16273, Saudi Arabia

3 Department of Civil Engineering, Faculty of Engineering and IT, Amran University, Amran 9677, Yemen

4 Polytechnic Institute, Far Eastern Federal University, 690922 Vladivostok, Russia; roman44@yandex.ru

5 Peter the Great St. Petersburg Polytechnic University, 195251 St. Petersburg, Russia; vatin@mail.ru

6 Belgorod State Technological University named after V.G. Shukhov, 308012 Belgorod, Russia; klyuyev@yandex.ru

* Correspondence: alhokabi93@gmail.com (A.A.-h.); m.amran@psau.edu.sa or mugahed_amran@hotmail.com (M.A.)

check for updates

Citation: Al-hokabi, A.; Hasan, M.; Amran, M.; Fediuk, R.; Vatin, N.I.; Klyuev, S. Improving the Early Properties of Treated Soft Kaolin Clay with Palm Oil Fuel Ash and Gypsum. Sustainability 2021, 13, 10910. https://doi.org/10.3390/su131910910

Academic Editor: Hailong Ye

Received: 17 June 2021

Accepted: 2 August 2021

Published: 30 September 2021

Publisher's Note: MDPI stays neutral with regard to jurisdictional claims in published maps and institutional affiliations.

Copyright: (c) 2021 by the authors. Licensee MDPI, Basel, Switzerland. This article is an open access article distributed under the terms and conditions of the Creative Commons Attribution (CC BY) license (https:/ / creativecommons.org/licenses/by/ $4.0 /)$.

\begin{abstract}
Soft soil problems and increased production of fuel waste have emerged due to world population growth. These two problems are prompting engineers to introduce new methods of using waste fuel to stabilize the soil. Previous research has shown clear sustained improvements in soil properties using palm oil fuel ash (POFA) when mixed with a calcium-based binder such as $\mathrm{NaCl}$, lime or cement. The use of such a stabilizing agent can reduce the economic problems associated with reducing the cost of waste disposal and create a sustainable ecological system. It is an alternative method of replacing part of the soil to ensure a balance between economic growth and ecological privilege, leading to the achievement of green technology goals. However, this research is aimed at improving the properties of processed soft kaolin clay with a combination of POFA and gypsum. The physical and mechanical properties of all samples were tested. The results showed a decrease in the specific gravity with the addition of POFA and an increase with gypsum alone, as well as a decrease with a mixture of POFA and gypsum and a decrease in the soil plasticity index due to a better increase in the plasticity limit compared to the liquid limit. This is considered a sign of improved geotechnical properties and reduced linear shrinkage. It was also shown that the treated clay showed an increase in the optimal water content and a drop in the maximum dry density. Nevertheless, it can be concluded that the initial properties of the processed soft kaolin clay with the addition of POFA can be significantly improved.
\end{abstract}

Keywords: soft soil; palm oil fuel ash; gypsum; soft kaolin clay; concrete; properties

\section{Introduction}

Global water presence in clay affects the behavior of it to either shrink or swell [1]. The swelling of expansive clay soil is a result of water content variation, which leads to significant destruction of overlying structures; thus, civil engineering researchers consider this issue [2]. Soil stabilization is the most economical way to improve the properties of the problematic soil; generally, soil stabilization is a method of modifying and enhancing soil properties by blending other materials. Improvements include increasing the compressive and shear strength and bearing capabilities to strengthen geotechnical properties and other applications [3]. When a stabilizer is mixed with soil, the action of change takes four stages. The first two stages are defined as soil modification and the last two stages are classified as stabilization. The first stage is cation exchange, followed by flocculation and agglomeration as a result of water 
reduction in the second stage. The third stage is known as a pozzolanic reaction, and lastly, the fourth stage is an autogenous healing process [4]. During the stabilization process, two main factors affect the mix design (stabilizer proportions) and the curing period (the curing period is one of the most significant parameters that has an impact on the extent of soil stabilization [5]). There are different ways of soil stabilization [6-9]. Researchers found that some of the byproduct waste materials, which contain a high amount of silica, alumina and lime, might enhance soil characteristics to minimize the issue. Engineers adopted a method of utilizing by-product waste to tackle both issues of problematic soil and massive daily production of biomass solid waste.

By-product materials are produced in massive quantities daily worldwide. They have a negative impact on sustainability and the environment due to the cost of disposal and potential contamination of land and groundwater caused by heavy metals which are part of their chemical composition contents [10,11]. Palm oil production has risen by more than four times in the past 25 years [12]. Biomass of the oil palm industry productions ranked the largest in Malaysia, where a large amount is useless, with 143 million tons of solid and liquid waste in 2012 [13]. Malaysia and Indonesia are the primary palm oil fuel ash (POFA) producers, manufacturing $86 \%$ of global supplies, according to [14]. It is also reported that Malaysia's annual production of raw palm oil is about 7 million tones, and it is increasing annually [15]. It is stated that Malaysia produces about 5 million tons of POFA only [16]. Given that open burning is no longer permitted [17], this residue is disposed of in landfills and consequently causes environmental problems such as air pollution and groundwater quality issues because of the leaching of different metals from the ash [18]. POFA contains a large amount of silica and has a high potential to be used as a pozzolanic material [19]. The chemical properties of POFA depend on the burning process, the raw materials used and the burning temperature $[20,21]$. Treatment of POFA to improve the chemical compositions properties and physical properties by grinding and thermal treatment to increase the fluidity, fineness and effectiveness leads to enhanced strength properties [22]. It is found that utilizing POFA to treat soft clays increased the plastic limit, and overall, utilizing POFA in soft clay treatment reduces the plasticity and improves the consistency of the treated soil, which can be attributed to the agglomeration and flocculation that occurred in the particles of the stabilized soil, as found by $[23,24]$.

Gypsum is mined and has applications in many products such as drywall used in construction, agriculture and industry [25,26]. Gypsum itself is a non-plastic material [27-29]. During the production, construction and demolition of gypsum plasterboards, about fifteen million tons of waste are generated yearly in the world [27,30]. It can be used as a soil amendment that can improve soil characteristics to allow for improved crop yields and soil structure [1]. However, we should consider that the high amount of gypsum in the soil increases the internal sulphate attack [31]. Gypsum is one of the materials used as an alternative in chemical improvement techniques by many researchers [32,33]. It is also found that gypsum partially applied in soil enhanced its physical and chemical properties. It absorbs more water and decreases soil loss, and this is known as the ionic strength effect [34]. The chemical properties of gypsum include a high amount of $\mathrm{CaO}$, which is one of the key factors of enhancing bonding between clay soil particles, as mentioned by [35]. An experimental study was conducted of soil mixed with different percentages of gypsum and it was found that 4\% gypsum marked the optimum dosage of gypsum [36]. The optimum moisture content and maximum dry density at $4 \%$ gypsum are $11.76 \%$ and $19.16 \mathrm{KN} / \mathrm{m}^{3}$, respectively. It is stated that the unconfined compressive strength increased with the addition of percentages of gypsum to the soft soil, but the UCS values reduced after $6 \%$ of gypsum [37].

Kaolin S300 is commonly treated before use because of its low strength and high settlement in the presence of water [38]. Kaolin is easily dispersed in water, having poor geotechnical properties, high plasticity and low workability $[39,40]$. POFA was used as a means of waste management and it has the potential to be used as a stabilizing agent due to the chemical compositions of POFA as alumina and silica [41,42]. On the other hand, 
gypsum also was added as a pozzolanic activator and stabilizer [43]. Further, soft soil issues and the increment in palm oil waste productions are in correspondence with the increment in global demand for oil because of world population growth. Malaysia is facing the two main issues that encourage engineers to adopt new methods of using palm oil waste in soil stabilization. Previous investigations have shown an apparent means of sustainable enhancement in soil properties by using POFA when mixed with a calcium-based binder such as $\mathrm{NaCl}$, lime or cement. Utilizing POFA as the stabilizing agent can reduce economic issues by reducing the cost of waste landfill and help attain a sustainable ecological system. To stabilize the soft soil, the addition of POFA and gypsum is required to investigate their effect on modifying the properties of the soil. This is an alternative method to replace some of the soil so that it balances between economic growth and environmental privilege that leads to achieving green technology goals.

The novelty of this study is focused on the use of both POFA as pozzolanic waste, and gypsum as binder as well as the inclusion of pozzolan activator to achieve better properties modification and soil stabilization to sustain a higher load. POFA is abundant and cost-effective, and it is a better method to dispose of it in the engineering field than in landfills. Gypsum is more economical than cement or lime; it can be produced in soil, mined and has no negative impact on environment. However, this study aims to improve the early properties of soft kaolin clay with the combination of POFA and gypsum. This study is presents the materials and methodology used, results, discussion and conclusions to explain the investigation and the effectiveness of POFA and gypsum in the stabilization of soft kaolin clay in terms of physical properties, compaction properties of optimum moisture content and maximum dry density.

\section{Materials and Methodology}

This research was basically planned to determine the physical properties and the variation of compaction characteristics of the original soft clay and clay treated with POFA and gypsum. The soft clay utilized in this experiment was kaolin; it was substituted and replaced with different percentages of gypsum and POFA. The flow of works followed standard laboratory test procedures and data analysis methods, according to British Standards (BS) and the American Society for Testing and Materials (ASTM). The specific gravity test was conducted according to BS 1377: Part 2: 1990: 8.3 [44]. The liquid limit was conducted according to BS 1377: Part 2: 1990: 4.3 [44], whereas the plastic limit test was conducted according to BS 1377: Part 2: 1990: 5.3 [44]. The linear shrinkage test was conducted according to BS 1377: Part 2: 1990: 6.5 [44]. A standard proctor test was carried out according to BS 1377: Part 4: 1990: 3.3 to determine compaction parameters (optimum moisture content and maximum dry unit weight) [44]. Figure 1 shows the experimental study workflow.

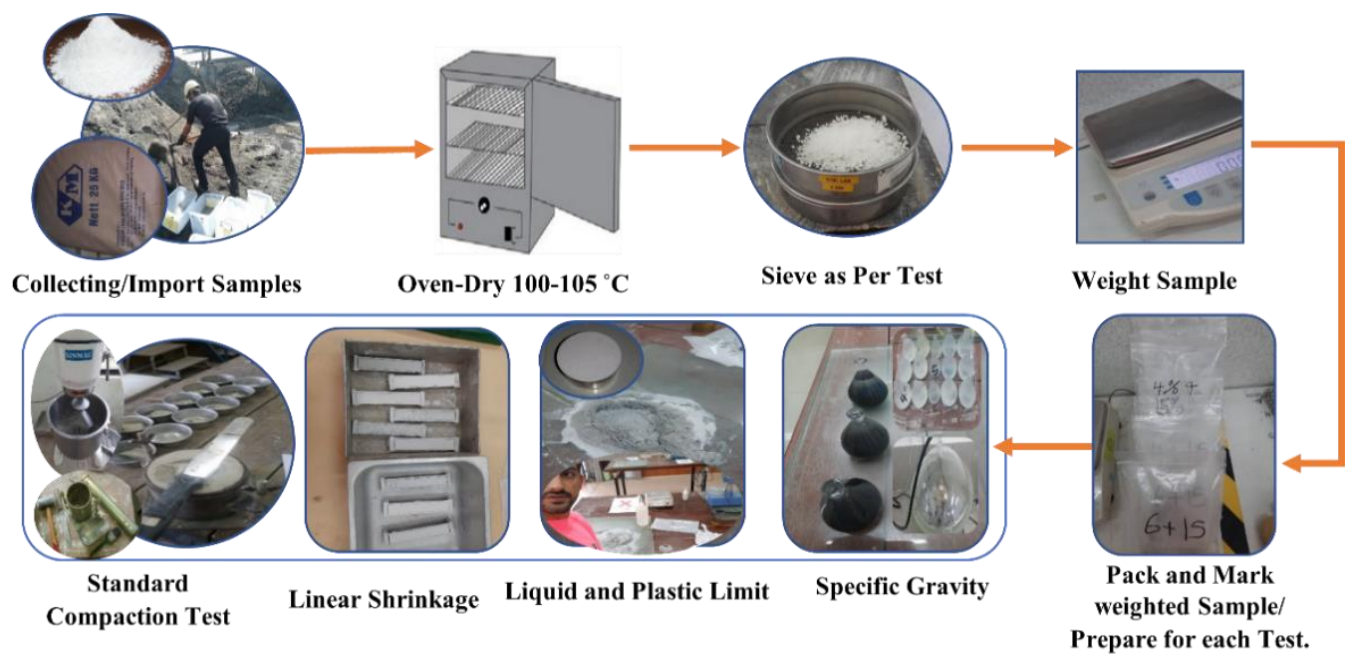

Figure 1. Experimental study workflow. 
Table 1 POFA and gypsum. Gypsum and kaolin were imported, whereas POFA was collected from LKPP Corporation Sdn.Bhd, Lepar Hilir Palm Oil Mill, Gambang, Kuantan, Pahang, Malaysia. The amount required of gypsum and POFA was added based on the dry weight of the kaolin S300. All materials were dried in the oven at $105^{\circ} \mathrm{C}$ for $24 \mathrm{~h}$. After that, the materials were sieved based on the specific sieve size per test in accordance with British Standard (BS). The mixture prepared was carefully mixed by using a soil mixer until the mixture looked homogenous before testing was carried out. The $4 \%$ and $6 \%$ gypsum were selected based on the literature review, whereas the POFA $(5 \%, 10 \%, 15 \%)$ percentages were randomly selected to test POFA usage in different amounts with gypsum to treat soil and investigate the enhancement of geotechnical physical and mechanical properties. All the tests were conducted with a minimum of three to five repeated times per sample per test to ensure the consistency and accuracy of the obtained results. Table 1 shows the twelve samples prepared and tested per test.

Table 1. Proportions of the used stabilizing agents.

\begin{tabular}{cccc}
\hline Kaolin (\%) & POFA (\%) & Gyp (\%) & Code \\
\hline 100 & 0 & 0 & K \\
96 & 0 & 4 & K4G \\
94 & 0 & 6 & K5P \\
95 & 5 & 0 & K10P \\
90 & 10 & 0 & K15P \\
85 & 15 & 0 & K4GP5 \\
91 & 5 & 4 & K4GP10 \\
86 & 10 & 4 & K4GP15 \\
81 & 15 & 4 & K6GP5 \\
89 & 5 & 6 & K6GP10 \\
79 & 10 & 6 & K6GP15 \\
\hline
\end{tabular}

\subsection{Test Setup and Procedures}

The specific gravity (SG) is the ratio between the mass of soil to its volume. It is essential in relation to other tests, especially for calculating porosity and voids. Kaolin, POFA and gypsum were sieved through a $2 \mathrm{~mm}$ sieve size and a small pycnometer test was used. Pycnometer bottles maximum capacity is $100 \mathrm{~mL}$ [45]. The specific gravity values of kaolin and POFA were obtained with distilled water, whereas gypsum's specific gravity was obtained using kerosene as dissolving material for gypsum because gypsum hardened when utilizing water to obtain specific gravity; the same method was used by $[46,47]$.

The liquid limits of kaolin, POFA and gypsum are determined by using the cone penetrometer method as it is more accurate and less liable to personal and experimental errors. The liquid limit is determined by obtaining a minimum of four points for plotting the curve. The consistency of the soil specimens is adjusted so the cone penetration ranges between $15 \mathrm{~mm}$ and $25 \mathrm{~mm}$. The plastic limits of kaolin, POFA and gypsum are determined from the rolling thread method. Liquid limit and plastic limit are very critical indicators corresponding to undrained shear strengths [48]. The liquid limit was conducted after taking a weight of the sample, $300 \mathrm{~g}$ (kaolin or kaolin+ POFA, kaolin+ gypsum or kaolin+ POFA+ gypsum), which passed a $425 \mu \mathrm{m}$ sieve. Then, distilled water was added to the soil specimen after it was mixed for at least $10 \mathrm{~min}$ to be homogenous and mixed with two spatulas. The well-mixed soil specimen was then put into the metal cup. The soil's liquid limit is obtained as moisture content at penetration at $20 \mathrm{~mm}$. The plastic limit represents the moisture content at which soil changes to dry to plastic where it is considered the upper strength limit of consistency. The method of rolling a thread is suggested by Casagrande [49]. The sample was rolled on a glass plate until it crumbled at a diameter of $3 \mathrm{~mm}$, weighed and then put in the oven for $24 \mathrm{~h}$; then, the dry samples were weighed. The plasticity index is a workability indicator defined by the difference between the liquid and 
plastic limit of soil. The most challenging aspects in the soil are shrinkage and swelling, relying on the study of soil plasticity.

Linear shrinkage is defined as the change in the length of the soil bar when dried in the range below the liquid limit [50], which can be calculated as a percentage of the oven-dried soil length to the initial length of the soil bar according to BS 1377: Part 2: 1990: 6.4. Samples were sieved and passed a $425 \mu \mathrm{m}$ sieve. The mold used was about $140 \pm 1 \mathrm{~mm}$ and had an internal radius of $12.5 \pm 0.5$. To establish consistent results, after obtaining the liquid limit per sample, water used for mixing was equal to the percentage of water obtained at $20 \mathrm{~mm}$ from liquid limit results [44]. The linear shrinkage test determines the shrinkage strain of elongated specimens placed in a mold and subjected to drying in an oven for $24 \mathrm{~h}$ [50]. Linear shrinkage is when the contained water content reduced from a specific range reaches the maximum loss of moisture content and there is no more volume change. Linear shrinkage is a sign that indicates the soil reactivity but not necessarily the particular clay present in the soil [51].

The procedure for conducting this test is described in BS 1377: Part 4 1990: 3.3 [44] and ASTM D 698 [52]. The test is conducted to obtain relationships between compacted dry density and soil moisture content, where the measurement of the degree of compaction can be identified in these terms. The materials were sieved and passed through $4.75 \mathrm{~mm}$. When water is mixed with soil, added in a sequent way of $5 \%$ until the mass of mold and mixture showed a drop in weight, water plays the role of a softening agent for the soil particles. In this situation, the soil particles near closer to each other. They are forced to move into a dense position. The sample was compacted in three layers with equal thickness into a metal of about $105 \mathrm{~mm}$ internal diameter and about $985 \mathrm{~cm}^{3}$ volume by a metal rammer with a $50 \mathrm{~mm}$ diameter circular face, weighing $2.5 \mathrm{~kg}$ and dropping from a height of $300 \mathrm{~mm}$ with 25 blows in the mold. The obtained samples were collected during the experiment to attain a representative graph on the variation of dry density with the addition of $5 \%$ of water. The effective compaction is determined by four dependents: dry density, water content, compaction type (heavy or light) and soil type. When water content added to the soil sample is plotted against dry densities for each cycle, the highest value in the curves is the most important point, as it highlights optimum moisture content (OMC) and the maximum dry density (MMD).

\subsection{Materials}

The kaolin powder grade S300 was used in this project. The used kaolin in our experiments is hydrous alumina silicate with the general chemical of formula $\mathrm{Al}_{2}\left(\mathrm{Si}_{2} \mathrm{O}_{5}\right)$ $(\mathrm{OH})_{4}$. Kaolin is considered as one of the huge natural resource deposits in Malaysia, which has around 112 million tones [53]. Kaolin is one of the tropical problematic soils that is exposed to volumetric change due to the seasonal water inconsistency [39]. It is selected to be treated due to its poor and expansive geotechnical properties, as it shows lows shear strength, high plasticity and low workability $[39,40,54]$.

POFA is a by-product material obtained by burning shells and empty fruit bunches in palm oil mill boilers heated at the rated temperature of $800-1000{ }^{\circ} \mathrm{C}$ to generate steam. The obtained steam avails as a source of energy utilized in turbines to supply electricity during the milling operation $[55,56]$. Raw POFA is unusable because of its unknown moisture content. The POFA is shown in Figure 2; it is a pozzolanic waste material from the palm oil industry. A large amount of amorphous silica in POFA potentially contributes to the pozzolanic reaction during hydration, which results in cementation compounds called calcium aluminate hydrates (CAH) and calcium silicate hydrates (CSH). These compounds are responsible for improving engineering characteristics of soil that increase over time as a pozzolanic reaction. POFA is generated in huge quantities, mainly in developing countries. Indonesia and Malaysia are the primary POFA producers, manufacturing $86 \%$ of global supplies according to [10]. 

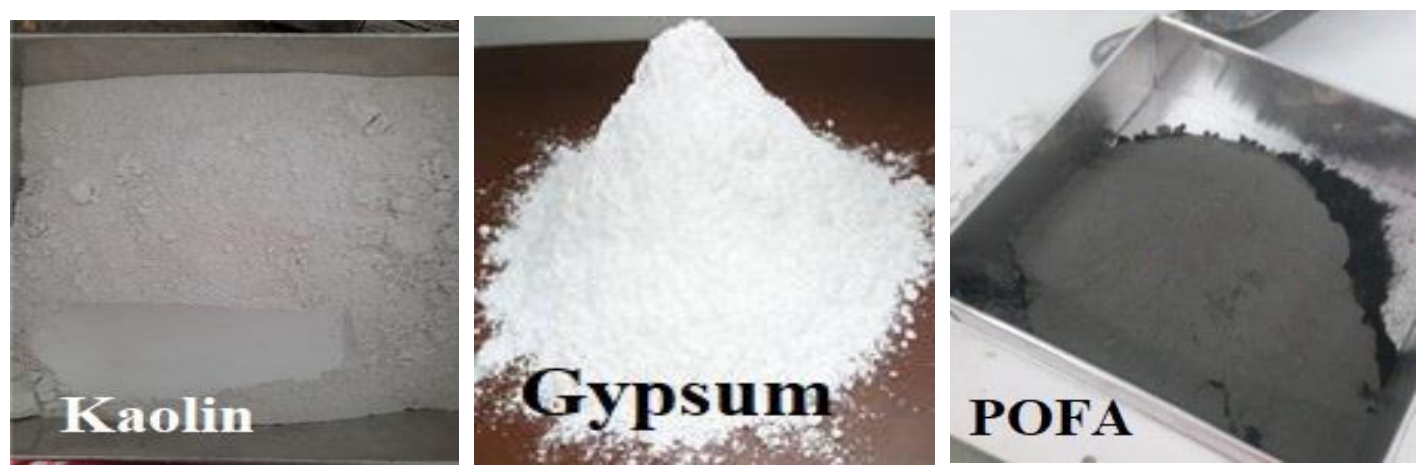

Figure 2. Kaolin, Gypsum and POFA used in Laboratory work.

Gypsum is a soft white mineral consisting of hydrated calcium sulphate, as shown in Figure 2; the chemical formula is calcium sulphate dihydrate $\left(\mathrm{CaSO}_{4} \cdot 2\left(\mathrm{H}_{2} \mathrm{O}\right)\right)$. It is a naturally occurring mineral that is comprised of calcium sulphate and water, and it is sometimes called hydrous calcium sulphate. Gypsum has better properties than organic additives because it does not cause air pollution and it is cheaper than cement, fire-resistant and resistant to deterioration by biological factors and chemicals $[29,57]$. It is also a byproduct of many industrial processes. It is suggested that both coagulation and cementation in soil may be achieved by the addition of gypsum and cement or lime, with significant improvements in soil structure [25]. Malaysia still considers the by-product of gypsum or red gypsum as scheduled waste [58].

Gypsum, POFA and kaolin samples are shown in Figure 2, which exhibits that the color of any material is influenced by the mineralogy property of the material. Gypsum is appeared to be white; while POFA had a black color, but the finer the POFA, the more greyish than black; and kaolin has a creamy to a whitish color. In terms of texture, kaolin is very fine, smooth and soft; POFA has a gritty sandy texture, but it seems to be wet and smooth in particles smaller than $0.425 \mathrm{~mm}$; and gypsum has a gritty, silty sand texture. Table 2 shows the chemical properties.

Table 2. Chemical Compositions of Kaolin, POFA, and Gypsum.

\begin{tabular}{lcccc}
\hline Material/Chemical Name & Component Formula & Kaolin & POFA & Gypsum \\
\hline Alumina & $\mathrm{Al}_{2} \mathrm{O}_{3}$ & 17.1 & 1.33 & 1.25 \\
Ferrite & $\mathrm{Fe}_{2} \mathrm{O}_{3}$ & 0.626 & 8.71 & 0.422 \\
Silica & $\mathrm{SiO}_{2}$ & 73.5 & 35.9 & 4.97 \\
Lime & $\mathrm{CaO}$ & - & 13.2 & 47 \\
Potassium Oxide & $\mathrm{K}_{2} \mathrm{O}$ & 7.23 & 35.4 & 0.756 \\
Magnesia & $\mathrm{MgO}$ & 0.79 & 1.24 & 0.816 \\
Sulfur trioxide & $\mathrm{SO}_{3}$ & 0.102 & 1.39 & 44.6 \\
Titanium dioxide & $\mathrm{TiO}_{2}$ & 0.343 & - & - \\
Phosphorus Pentoxide & $\mathrm{P}_{2} \mathrm{O}_{5}$ & - & 1.91 & 0.164 \\
Manganese(II) oxide & $\mathrm{MnO}$ & - & 0.257 & - \\
Chlorine & $\mathrm{Cl}$ & - & 0.256 & - \\
\hline
\end{tabular}

\section{Results and Discussions}

\subsection{Physical Properties}

\subsubsection{Particle Size Distribution}

The analysis of particle size curves for representing samples are displayed in Figures 3 and 4 . From the graph, approximately $76 \%$ of kaolin passed through sieve $0.075 \mathrm{~mm}$; further, $43 \%$ passed sieve \#270 (0.053 $\mathrm{mm})$ with uniformity coefficient $\mathrm{Cu}=1.6$ and curvature coefficient $C C=0.87$, which meant that the average size of the kaolin particles analysis was in the range of $0.001 \mathrm{~mm}$ to $0.2 \mathrm{~mm}$ (clay to fine silt). Therefore, with the corresponding results obtained from consistency limits tests, kaolin is classified as a 
fine-grained clayey silt (ML), according to USCS and classified under Group A-6 under AASHTO. POFA was classified as (SM) a poorly graded silty sand, corresponding to USCS, as $95 \%$ passed \#4 $(4.75 \mathrm{~mm})$, only $19 \%$ passed through sieve \#200 $(0.075 \mathrm{~mm})$ and $10 \%$ passed sieve \#270 $(0.053 \mathrm{~mm})$ with uniformity coefficient $\mathrm{Cu}=4$ and curvature coefficient $\mathrm{CC}=1$. The sieve analysis of gypsum showed that only $4 \%$ passed through sieve $0.075 \mathrm{~mm}$; therefore, it is also classified as poorly graded sand and (SP) according to USCS, with $\mathrm{Cu}=2.2$.

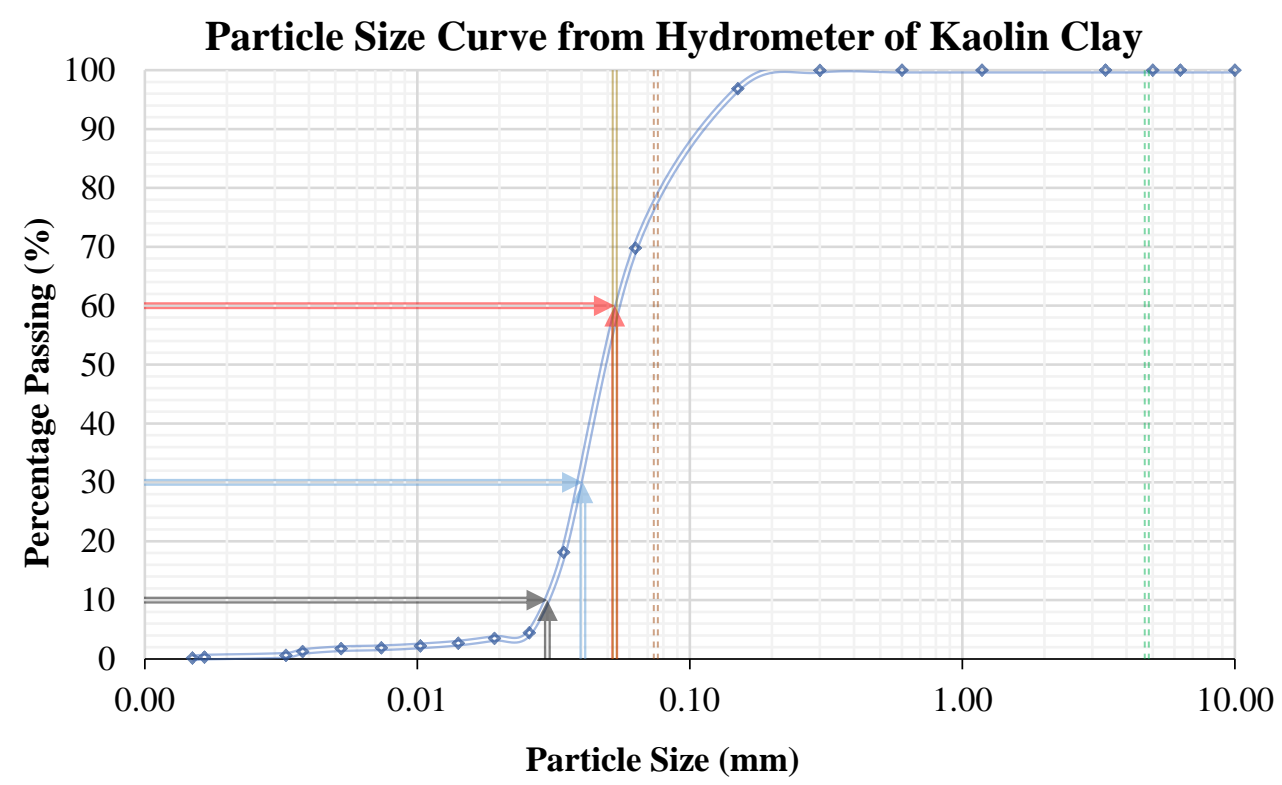

Figure 3. Particle size distribution of original kaolin clay.

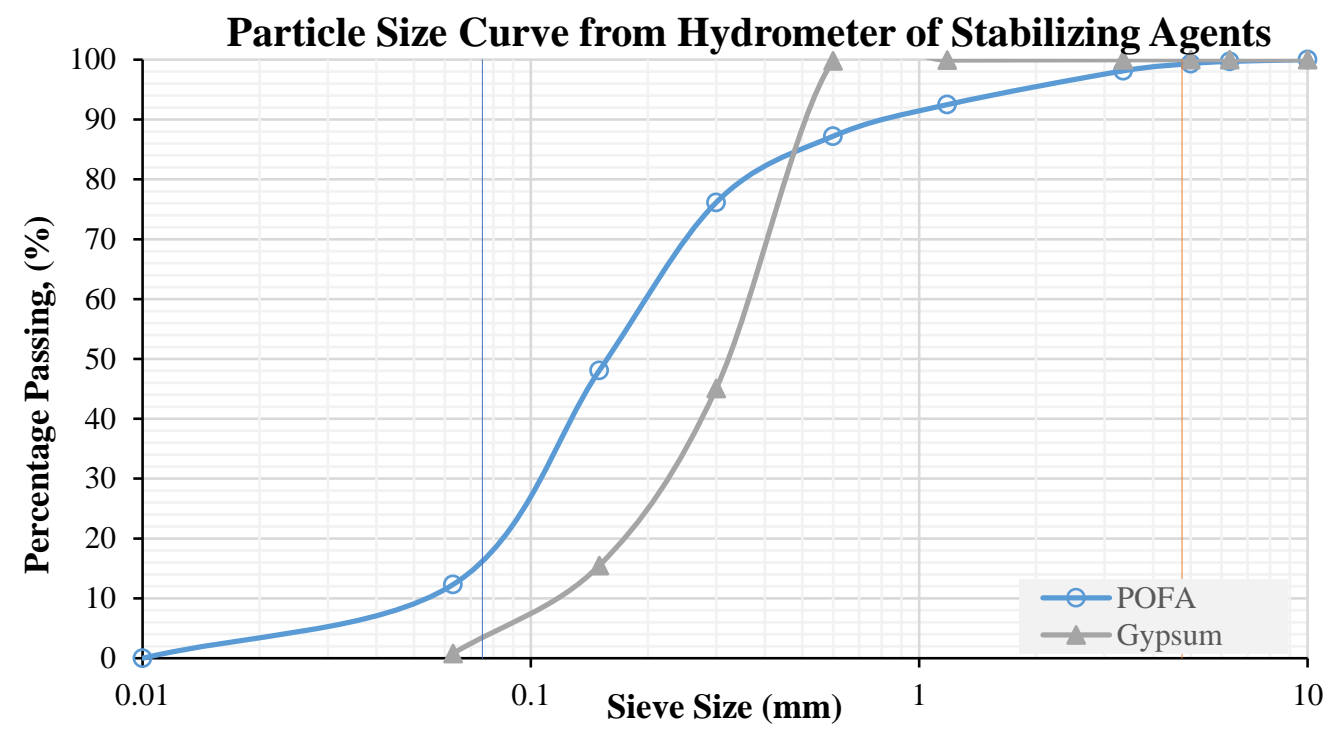

Figure 4. Particle size distribution of stabilizing agents (POFA and gypsum).

\subsubsection{Natural Water Content and Specific Gravity}

The kaolin, POFA and gypsum were analyzed for natural moisture content directly after being imported and collected. Table 3 illustrates the particle density and natural water content of kaolin, POFA and gypsum. As POFA was collected from an open area, the natural moisture content was the highest, whereas it had the lowest specific gravity. Kaolin marked the highest specific gravity, followed by gypsum. The reason behind the low specific gravity of POFA is because it contains some fibers, and previous researchers found that the specific gravity of POFA can be increased with burning, grinding and treatment, 
and results confirmed that the finer the POFA, the higher the value of specific gravity $[21,59]$. Various factors affect the specific gravity, one of them being the fineness of the material, where a higher proportion of silt corresponds to higher specific gravity [60]. The POFA, as an example, is affected by the treatment processes and the burning temperature. The $\mathrm{m}$ finer it is, the higher the specific gravity $[21,59]$.

Table 3. Summary of particle density and natural water content of materials.

\begin{tabular}{ccc}
\hline Sample & Specific Gravity, SG $\left(\mathbf{g} / \mathbf{c m}^{\mathbf{3}}\right)$ & Natural Moisture Content (\%) \\
\hline Kaolin & 2.71 & 0.457 \\
POFA & 2.25 & 4.494 \\
Gypsum & 2.66 & 1.093 \\
\hline
\end{tabular}

From Figure 5, K4GP10 showed the lowest specific gravity of $2.59 \mathrm{~g} / \mathrm{cm}^{3}$, followed by K6GP15, with specific gravity of $2.60 \mathrm{~g} / \mathrm{cm}^{3}$; in contrast, the highest specific gravity is of $\mathrm{K} 6 \mathrm{G}$, which reached a value of $2.78 \mathrm{~g} / \mathrm{cm}^{3}$, followed by $\mathrm{K} 4 \mathrm{G}$, with a value $2.74 \mathrm{~g} / \mathrm{cm}^{3}$. The specific gravity of kaolin was decreased when POFA was applied alone-it dropped from $2.69 \mathrm{~g} / \mathrm{cm}^{3}$ to $2.61 \mathrm{~g} / \mathrm{cm}^{3}$ compared to the specific gravity of original kaolin, which is $2.70 \mathrm{~g} / \mathrm{cm}^{3}$. On the other hand, it was increased with the addition of gypsum alone. The overall mixture of both POFA and gypsum demonstrated a reduction in the specific gravity lower than the original soil. One reason behind the specific gravity reduction is due to the low specific gravity of POFA compared to kaolin. Another reason might be the high amount of lightweight buoyant fibrous material in POFA, which float on water. The chemical reactions of POFA and gypsum also play a role in the reduction, where gypsum alone with clay showed an opposite result. An overall investigation of treated clay showed a clear decrement in its specific gravity with the addition of POFA and gypsum.

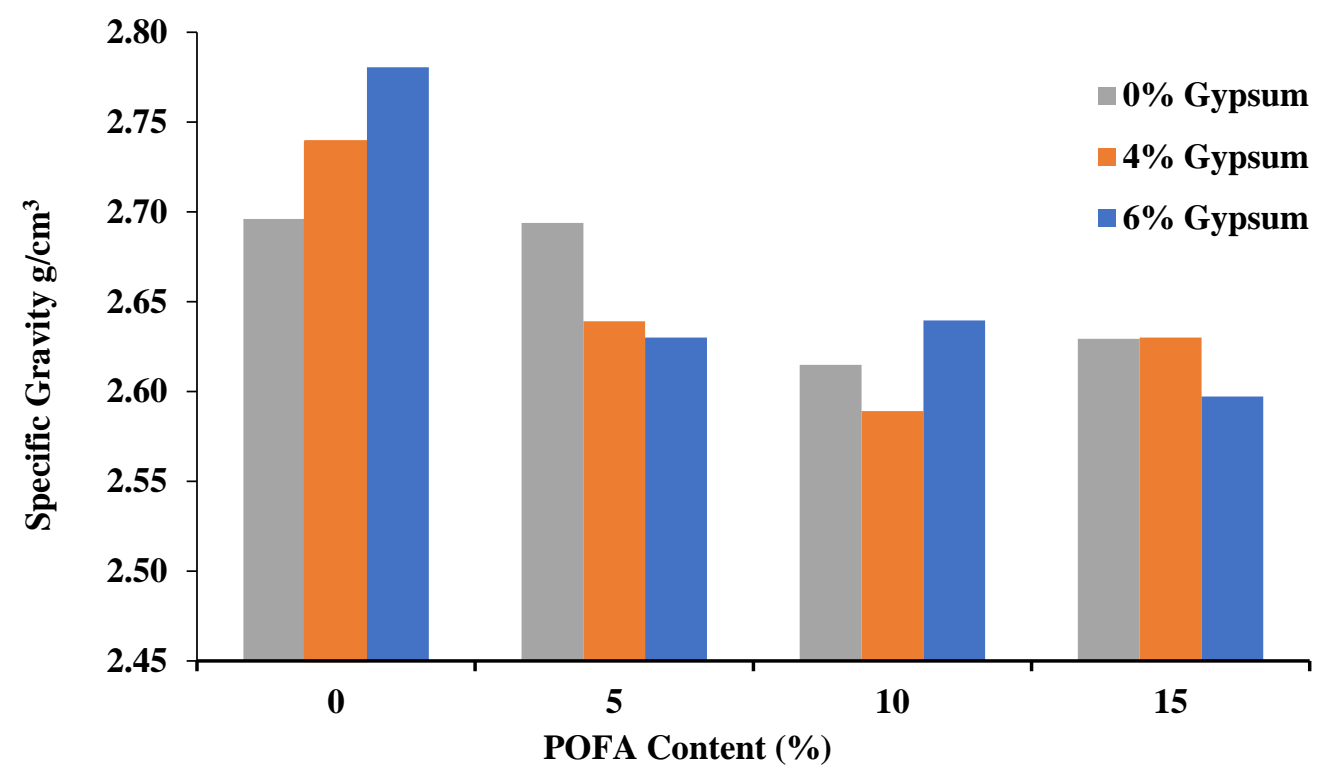

Figure 5. Specific gravity of kaolin and treated kaolin with POFA and gypsum.

\subsubsection{Liquid Limit}

Figure 6 illustrates the liquid limit results of both untreated and treated kaolin. The addition of POFA and gypsum mixed with kaolin increased its liquid limit. K4GP15 showed the highest value of $43.11 \%$ water content, followed by K6GP15 with $42.60 \%$. Gypsum alone at 4\% and 6\% also showed a slight increment in the liquid limit value, from $40.18 \%$ for original soil to $40.30 \%$ and $41.19 \%$, respectively. POFA alone mixed with kaolin absorbed much water and showed higher liquid limit in samples K5P, K10P and K15P. One reason for the increment may be the high amount of fiber in POFA, which 
absorbs a significant amount of water, or it might be the increase in $\mathrm{CaO}$ content in POFA and gypsum, which usually absorb more water; these results agree with those of $[10,37]$. Another reason for the increment in the liquid limit might be due to an elongation of the diffuse double layer as a result of the increment in the specific surface area, which assisted in the soft soil's capacity to hold more water; the results showed agreement with soft clay treated with high calcium fly ash investigated by [61]. It was also found that by adding a small amount of ultrafine POFA, the liquid limit increased [24], whereas by adding more than $10 \%$, the liquid limit decreased as along with the plastic limit, which agrees with the results found in this work. In general, the drop in soil plasticity due to using of POFA and POFA-blended gypsum is a sign of enhancement. It was also reported that the high porosity of binder materials with an agglomerated morphology could lead to a reduction in the workability due to the increase in the water absorbed by the large open areas of high porosity POFA [61]. Table 4 shows the standard deviation and variance per sample for the liquid limit tests.

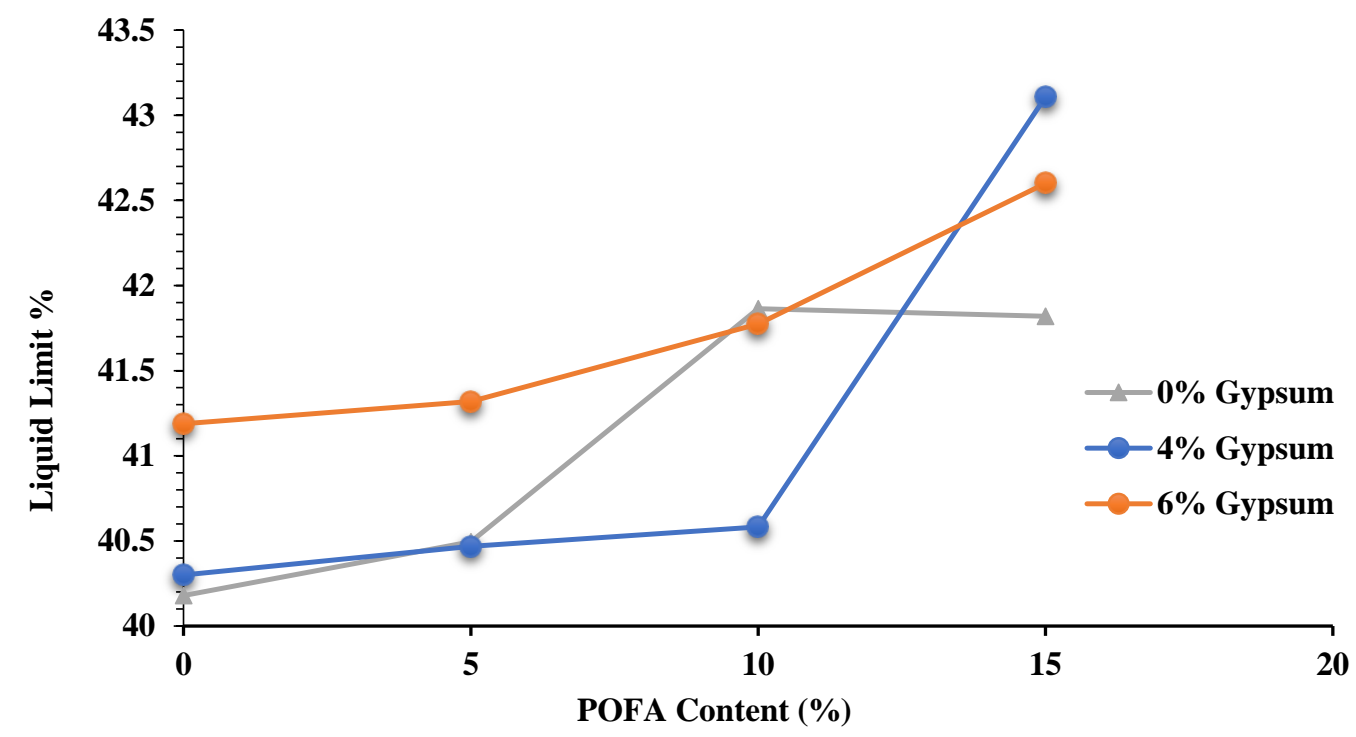

Figure 6. Liquid limit of kaolin treated with various dosages of POFA.

Table 4. Summary of standard deviation and variance of the specimen of liquid limit.

\begin{tabular}{cccccc}
\hline Sample & $\begin{array}{c}\text { Standard } \\
\text { Deviation }\end{array}$ & Variance & Sample & $\begin{array}{c}\text { Standard } \\
\text { Deviation }\end{array}$ & Variance \\
\hline K & 0.874 & 0.022 & K4GP5 & 0.454 & 0.011 \\
KG4 & 0.252 & 0.006 & K4GP10 & 1.302 & 0.031 \\
KG6 & 0.234 & 0.006 & K4GP15 & 0.248 & 0.006 \\
KP5 & 0.671 & 0.017 & K6GP5 & 0.124 & 0.003 \\
KP10 & 0.374 & 0.009 & K6GP10 & 0.438 & 0.011 \\
KP15 & 0.060 & 0.0014 & K6GP15 & 0.033 & 0.0008 \\
\hline
\end{tabular}

\subsubsection{Plastic Limit}

The plastic limit of the control sample is $30.72 \%$, as shown in Figure 7. It is apparent that the plastic limit was increased, save for a reduction with the addition of sole gypsum to kaolin in KG4 and KG6. It then showed a drop to 29.85\% and 29.24\% in K5P and K6GP5, respectively. On the other hand, overall increments were detected in all other samples, especially with the addition of POFA. K4GP15 marked the highest plastic limit of 35.27\% followed by K6GP15 with a plastic limit of $35.16 \%$. The previous reasons described as affecting the increment in the liquid limit also affected the plastic limit. It is also interpreted that a constant increment might be attributed to the agglomeration and flocculation that occurred in the particles of the POFA-treated soil, similar to a study on clay treated with 
POFA and calcium carbide conducted by $[23,61]$. The enhancement of the plastic limit referred to the change in the index of plasticity from silt with medium plasticity to low plasticity because of the addition of POFA and gypsum, which have a higher particle size than kaolin [62]. Table 5 shows the standard deviation and variance per sample for plastic limit tests.

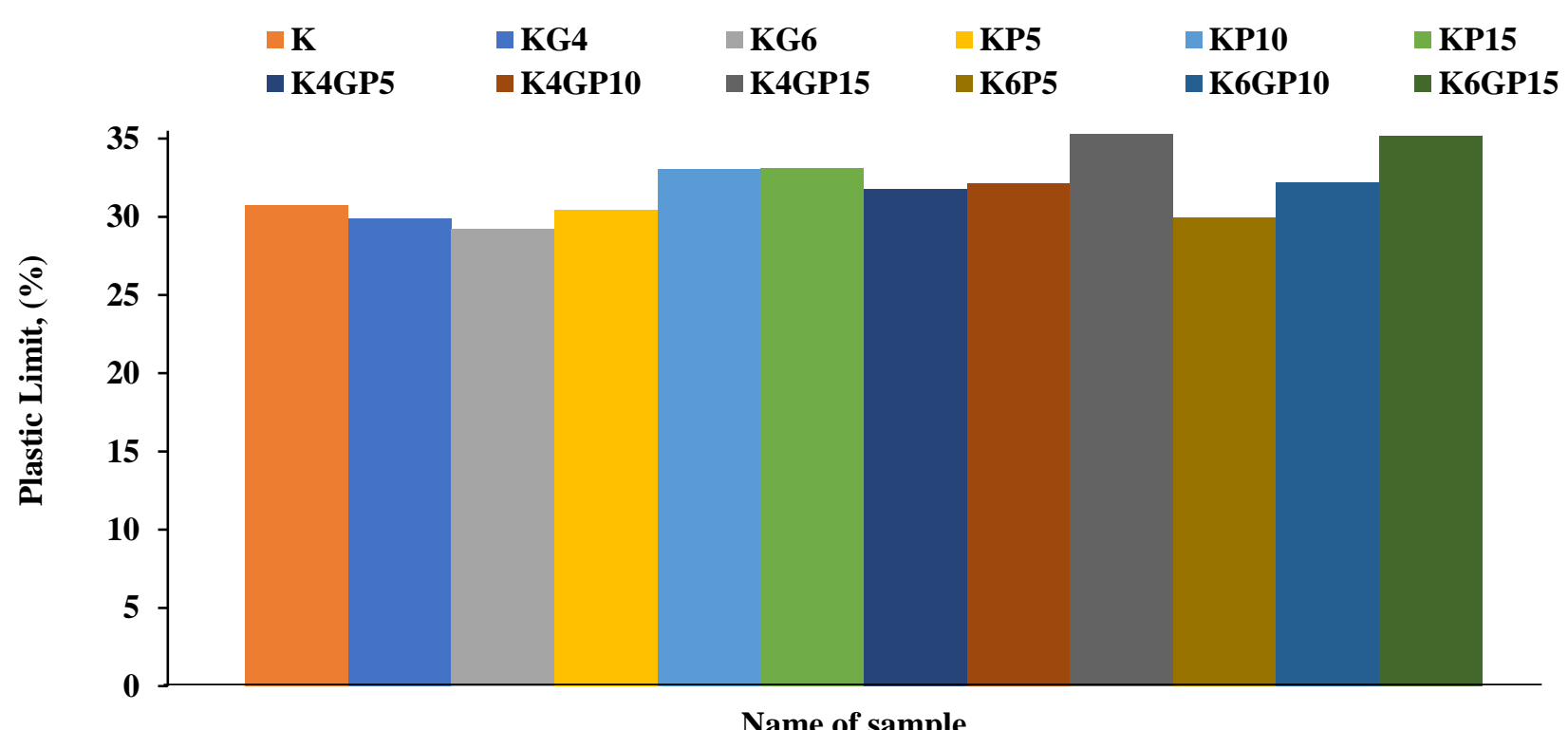

Figure 7. Plastic limit of kaolin treated with various dosages of POFA.

Table 5. Summary of standard deviation and variance of the specimen of plastic limit.

\begin{tabular}{cccccc}
\hline Sample & Standard Deviation & Variance & Sample & Standard Deviation & Variance \\
\hline K & 0.737 & 0.024 & K4GP5 & 0.677 & 0.022 \\
KG4 & 0.058 & 0.0019 & K4GP10 & 1.684 & 0.050 \\
KG6 & 0.492 & 0.0166 & K4GP15 & 0.187 & 0.006 \\
KP5 & 1.442 & 0.048 & K6GP5 & 0.323 & 0.011 \\
KP10 & 1.526 & 0.045 & K6GP10 & 0.175 & 0.005 \\
KP15 & 1.135 & 0.0335 & K6GP15 & 0.325 & 0.0092 \\
\hline
\end{tabular}

\subsubsection{Plasticity Index}

From Figure 8, it can be seen that even though the plasticity index is reduced by adding POFA, more POFA corresponds to more deduction in plasticity index value. The plasticity index was slightly increased with the addition of gypsum because of the clear raise in soil plastic limit to a tendency higher than the increment in the liquid limit with the addition of both POFA and gypsum. K4G, K6G and K6GP5 showed a small increment due to the chemical reaction of soil with gypsum. K4GP15 was marked by the lowest plasticity index, with $7.84 \%$. Consistency limits of treated soil with gypsum found that the decrement of the PI is controlled by shearing resistance and the double-layered diffusion of clay [25]. Table 6 demonstrates the standard deviation and variance per sample for plasticity index.

Table 6. Summary of standard deviation and variance of the specimen of plasticity index.

\begin{tabular}{cccccc}
\hline Sample & Standard Deviation & Variance & Sample & Standard Deviation & Variance \\
\hline K & 1.30 & 0.145 & K4GP5 & 0.956 & 0.098 \\
KG4 & 0.310 & 0.030 & K4GP10 & 0.382 & 0.047 \\
KG6 & 0.258 & 0.017 & K4GP15 & 0.435 & 0.058 \\
KP5 & 1.949 & 0.198 & K6GP5 & 0.447 & 0.038 \\
KP10 & 1.899 & 0.235 & K6GP10 & 0.263 & 0.028 \\
KP15 & 1.075 & 0.135 & K6GP15 & 0.293 & 0.040 \\
\hline
\end{tabular}




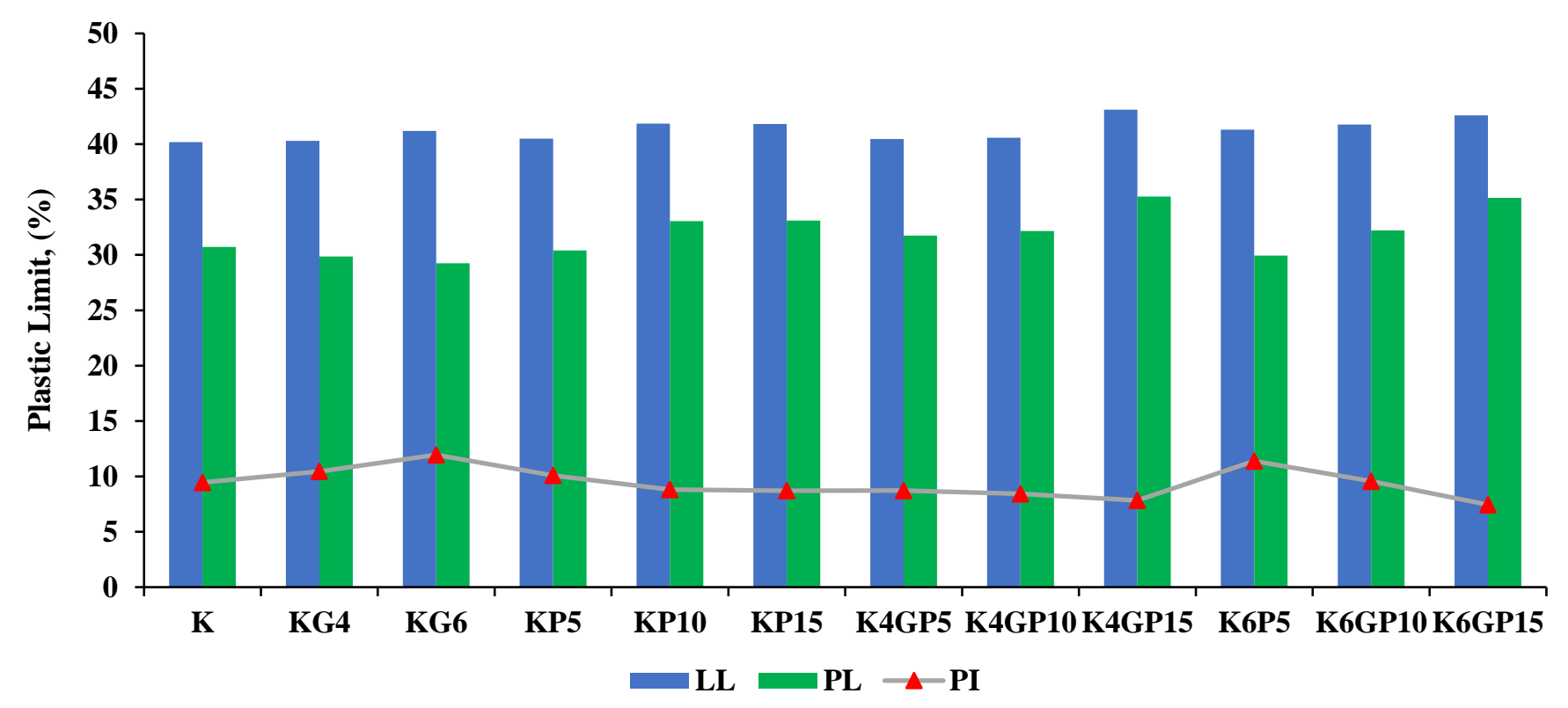

Figure 8. Plasticity index of kaolin treated with gypsum and POFA.

\subsubsection{Linear Shrinkage}

The results of linear shrinkage in Figure 9 show that kaolin does not have a high tendency to shrink, as only a $1.55 \%$ reduction in the mold length occurred. The results show that linear shrinkage was generally reduced with the addition of POFA or gypsum, where KG6 illustrated the lowest value of linear shrinkage with only $0.5 \%$, followed by KP15 with $0.77 \%$. The linear shrinkage showed a different reaction with the mixture of both POFA and gypsum. The value increased to $2.13 \%$ for K6GP10, which marked the highest overall value among all samples. The slight reduction that occurred is predictable due to the chemical reactions between gypsum with POFA and clay, which lead to the reduction in plasticity properties and related linear shrinkage [50].

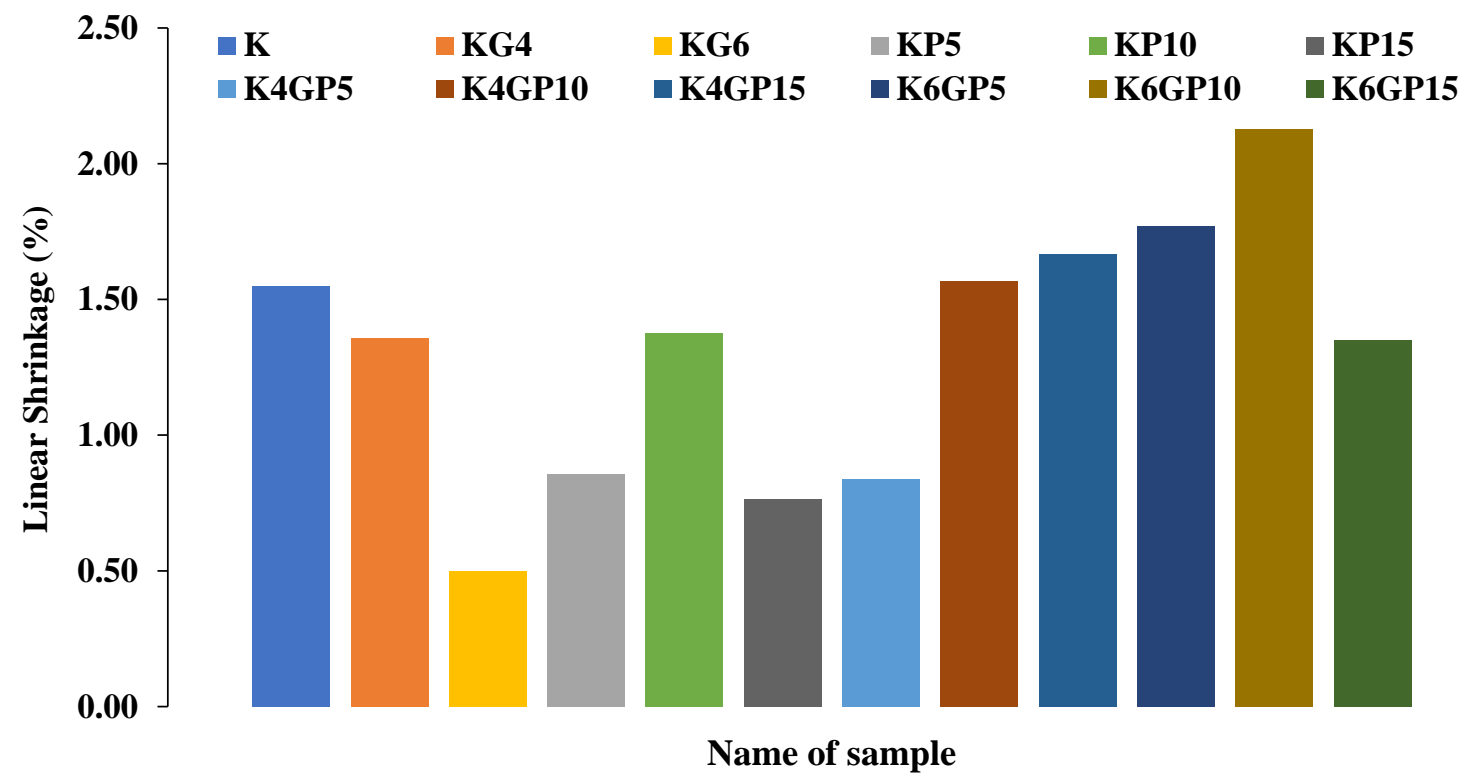

Figure 9. Linear shrinkage of kaolin and treated kaolin with POFA and gypsum. 


\subsection{Mechanical Properties}

\subsubsection{Variation of Dry Density with Addition of Water}

The compaction curves were plotted, as shown in Figures 10-13. From Figure 10, water absorption was increased by adding POFA dosage; it is apparent that with more POFA, higher water content is needed to obtain the optimum moisture content and maximum dry density. With the addition of more POFA content to kaolin, the maximum dry density achieved was decreasing accordingly. It can be interpreted as the POFA having lower specific gravity compared to kaolin and gypsum. The results showed an increase in OMC of the treated kaolin with POFA, results which are in line with previous work [63-66]. The referred increment can be explained as a result of crowding out of calcium ions released from POFA during ionic dissociation of hydrolyzed calcium oxide of POFA and pozzolanic reaction between calcium ions of POFA and $\mathrm{SiO}_{2}$ in kaolin, where both are considered as a factor of soil chemical stabilization.

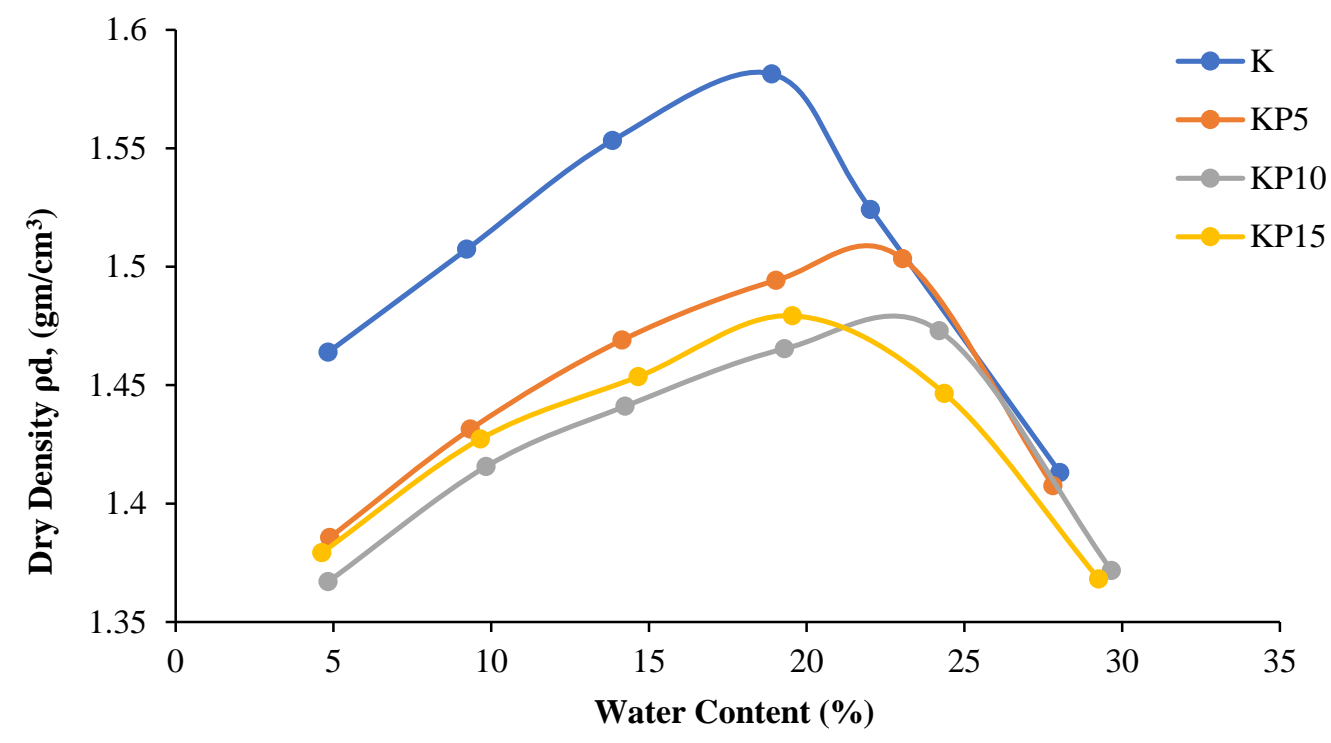

Figure 10. Variation of MDD and OMC of treated kaolin with various POFA content.

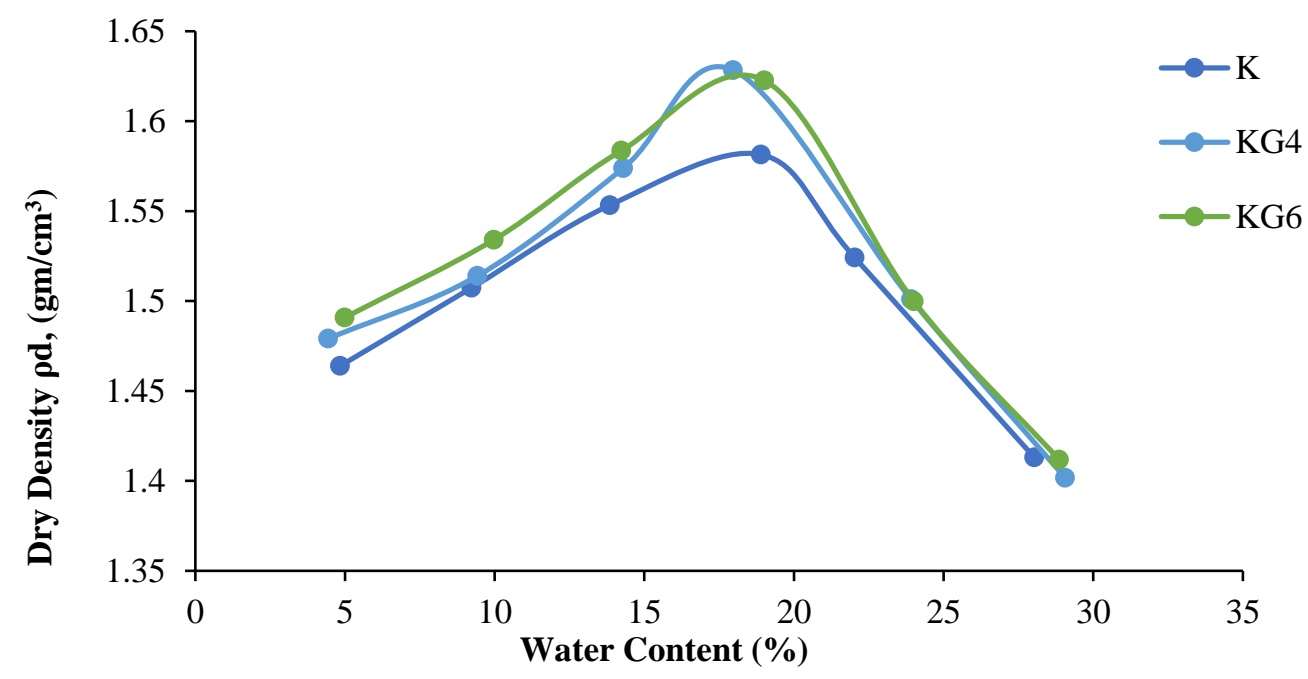

Figure 11. Variation of MDD and OMC of treated kaolin with gypsum content. 


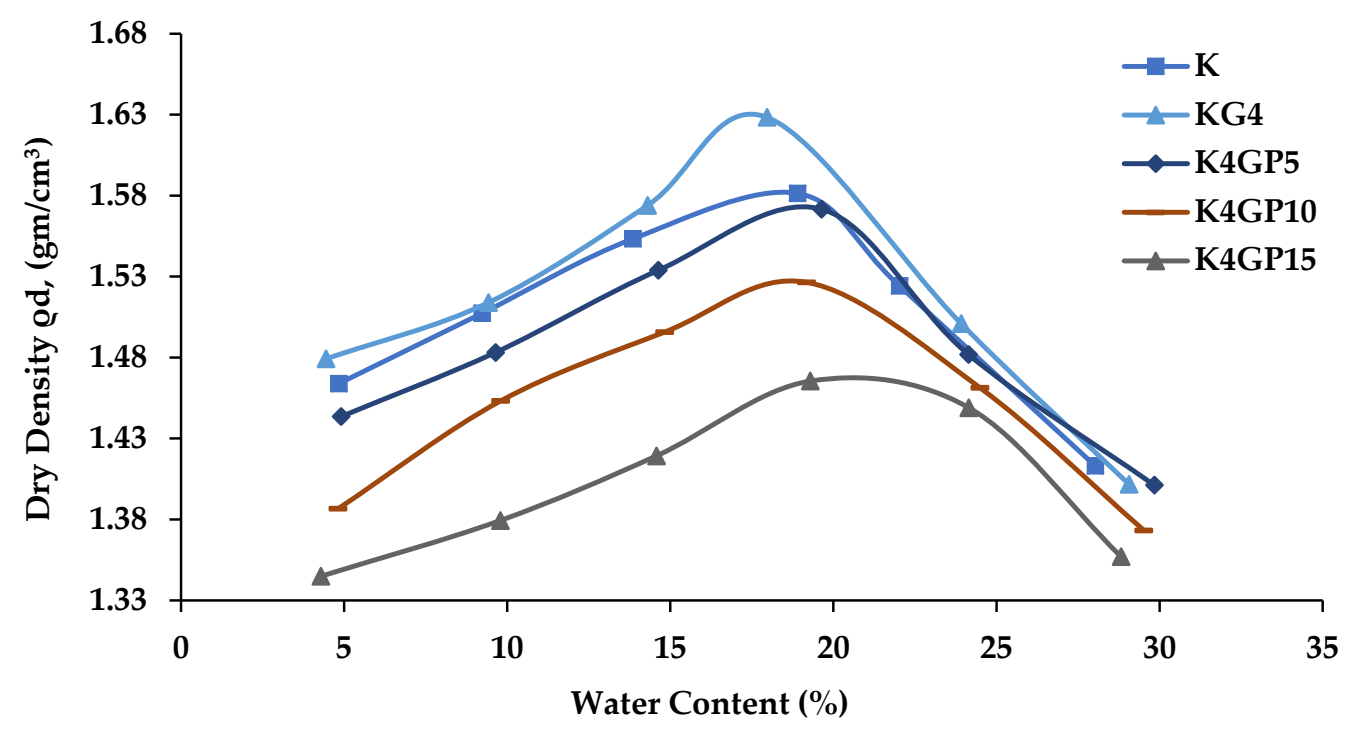

Figure 12. Variation of MDD and OMC of treated kaolin with $4 \%$ gypsum and various POFA content.

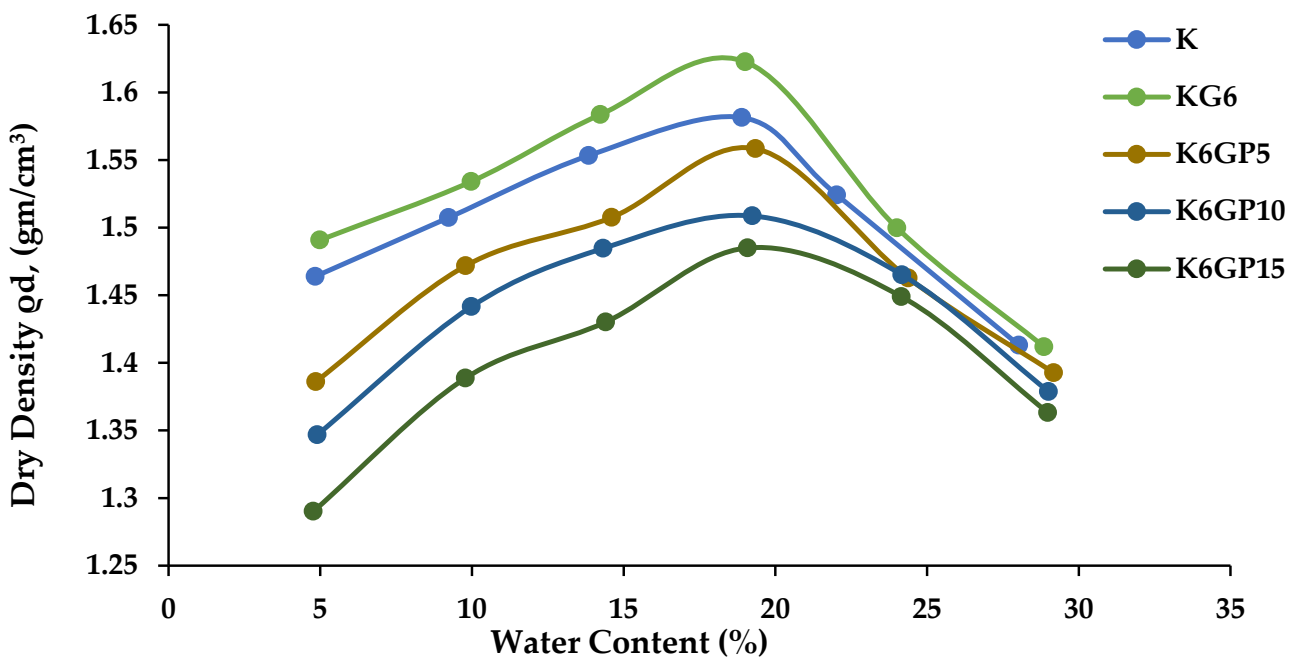

Figure 13. Variation of MDD and OMC of treated kaolin with $4 \%$ gypsum and various POFA content.

As seen in Figure 11, there was a slight reduction in maximum dry density and increment in the optimum water content of the treated samples with the addition of gypsum. The change in standard compaction test results was not high with the addition of gypsum only, compared to the control sample. These results agree with previous research works that reported that the addition of gypsum to clay soil can increase the absorption of water content needed for the chemical reaction [34].

The addition of different percentages of POFA with $4 \%$ and $6 \%$ of gypsum content is shown in Figure 12. The maximum dry density of KG4 and KG6, $1.63 \mathrm{gm} / \mathrm{cm}^{3}$ and $1.62 \mathrm{gm} / \mathrm{cm}^{3}$, respectively, was higher than the control sample, but it slightly dropped to reach the lowest at K4GP15 with $1.46 \mathrm{gm} / \mathrm{cm}^{3}$ compared to $1.58 \mathrm{gm} / \mathrm{cm}^{3}$ as MDD of kaolin. This can be explained as a result of higher water absorption required by porous POFA, which conquers the pore space of POFA soil and leads to particle buoyancy [65]. The higher amount of fiber in the added POFA also affected the reduction in maximum dry density and the specific gravity of treated clay $[19,67]$. The reduction in maximum dry density might be due to the resistance of compaction as a result of the flocculation of soil particles during soil stabilization [5]. 


\subsubsection{Maximum Dry Density (MDD)}

The maximum dry density increased from $1.59 \mathrm{gm} / \mathrm{cm}^{3}$ for kaolin alone to $1.63 \mathrm{~g} / \mathrm{cm}^{3}$ and $1.62 \mathrm{~g} / \mathrm{cm}^{3}$ for $\mathrm{K} 4 \mathrm{G}$ and $\mathrm{K} 6 \mathrm{G}$, respectively, as the gypsum absorbs more water during compaction, as shown in Figure 15; these results are in line with those presented by [32,35,68,69]. However, when adding up $5 \%, 10 \%$ and $15 \%$ of POFA with gypsum, the MDD continued to drop until reaching $1.465 \mathrm{~g} / \mathrm{cm}^{3}$ for K6GP15 as the lowest. On the other hand, POFA alone mixed with kaolin of $15 \%$ started to increase, as the maximum dry density of K10P is $1.475 \mathrm{~g} / \mathrm{cm}^{3}$ whereas K15P reached $1.482 \mathrm{~g} / \mathrm{cm}^{3}$. A drop in the maximum dry density value by adding POFA is predicted due to the too low specific gravity of POFA (2.25) [67]. Previous results on POFA used as a stabilizer with lime conducted by [19] found that the density of soil is affected by lime content—predicted to be present in our gypsum —where the lime tends to absorb the water and hence, decrease the maximum dry density of treated soil. The maximum dry densities of kaolin and treated kaolin are shown in Figure 14. Table 7 displays the standard deviation and variance per sample for the liquid limit tests.

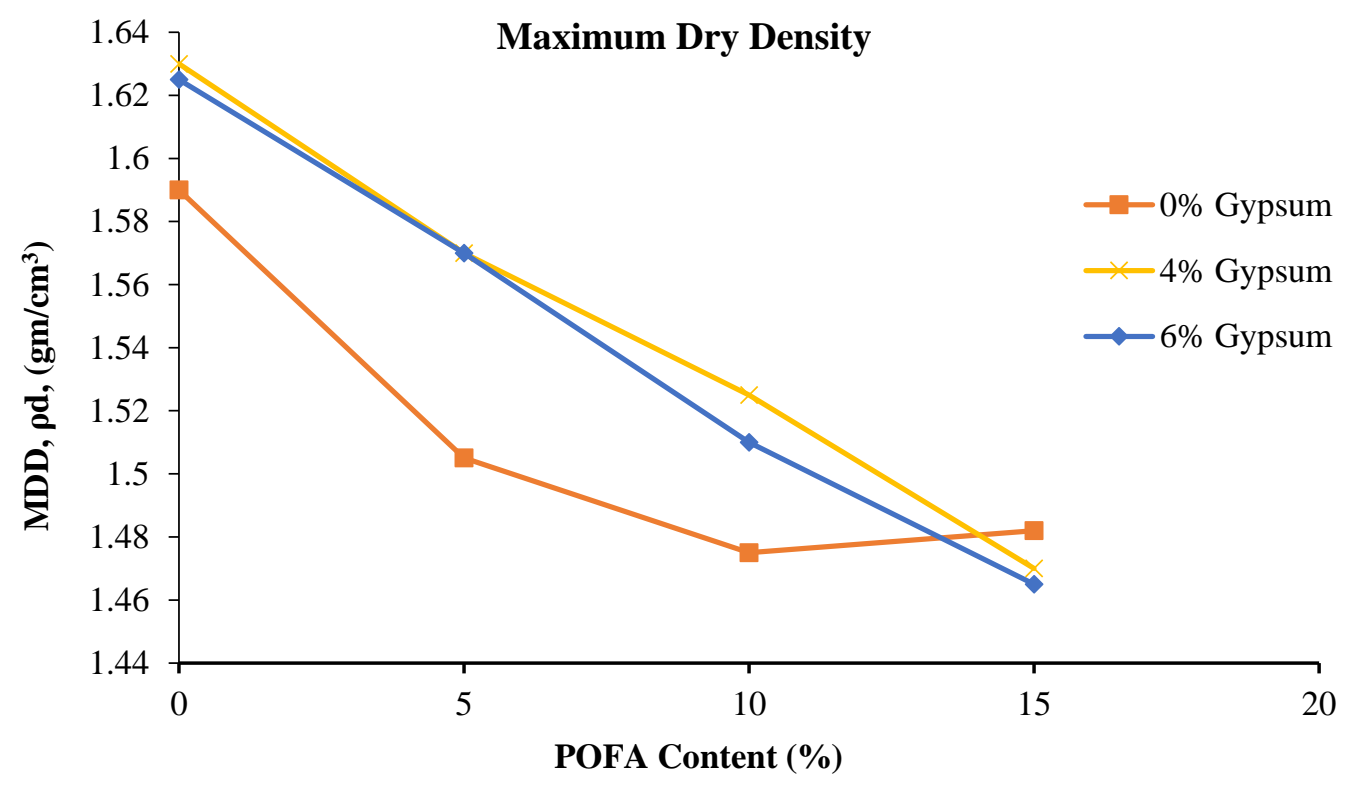

Figure 14. MDD of treated kaolin with various POFA content and gypsum.

Table 7. Summary of standard deviation and variance of MDD.

\begin{tabular}{cccccc}
\hline Sample & $\begin{array}{c}\text { Standard } \\
\text { Deviation }\end{array}$ & Variance & Sample & $\begin{array}{c}\text { Standard } \\
\text { Deviation }\end{array}$ & Variance \\
\hline K & 0.007 & 0.004 & K4GP5 & 0.035 & 0.022 \\
KG4 & 0.021 & 0.013 & K4GP10 & 0.028 & 0.019 \\
KG6 & 0 & 0 & K4GP15 & 0.006 & 0.004 \\
KP5 & 0.0035 & 0.0024 & K6GP5 & 0.007 & 0.005 \\
KP10 & 0.007 & 0.005 & K6GP10 & 0.007 & 0.005 \\
KP15 & 0.014 & 0.0095 & K6GP15 & 0.021 & 0.014 \\
\hline
\end{tabular}

\subsubsection{Optimum Moisture Content (OMC)}

The optimum water content of kaolin and POFA-gypsum-treated kaolin is shown in Figure 15. The optimum water content increased because the tendency of POFA for water absorption is high. This tendency is clearly explained by OMC, which increased from $18 \%$ for the control sample to $24 \%$ for KP10, but when adding more POFA, the water content drops until reaching $19.2 \%$ for KP15. The water content is slowly increased when gypsum is added compared to the values of POFA, therefore, with kaolin soil, the more POFA added, the higher the optimum moisture content achieved, similar to results published by $[30,65,67,70]$. The high amount of $\mathrm{CaO}$ in gypsum can be one of the reasons behind the 
increment in water absorption by treated soil; [3] mentioned that lime is known to decrease the plasticity index and maximum dry density of the soil and increase its optimum water content. Table 8 summaries the standard deviation and variance of OMC values.

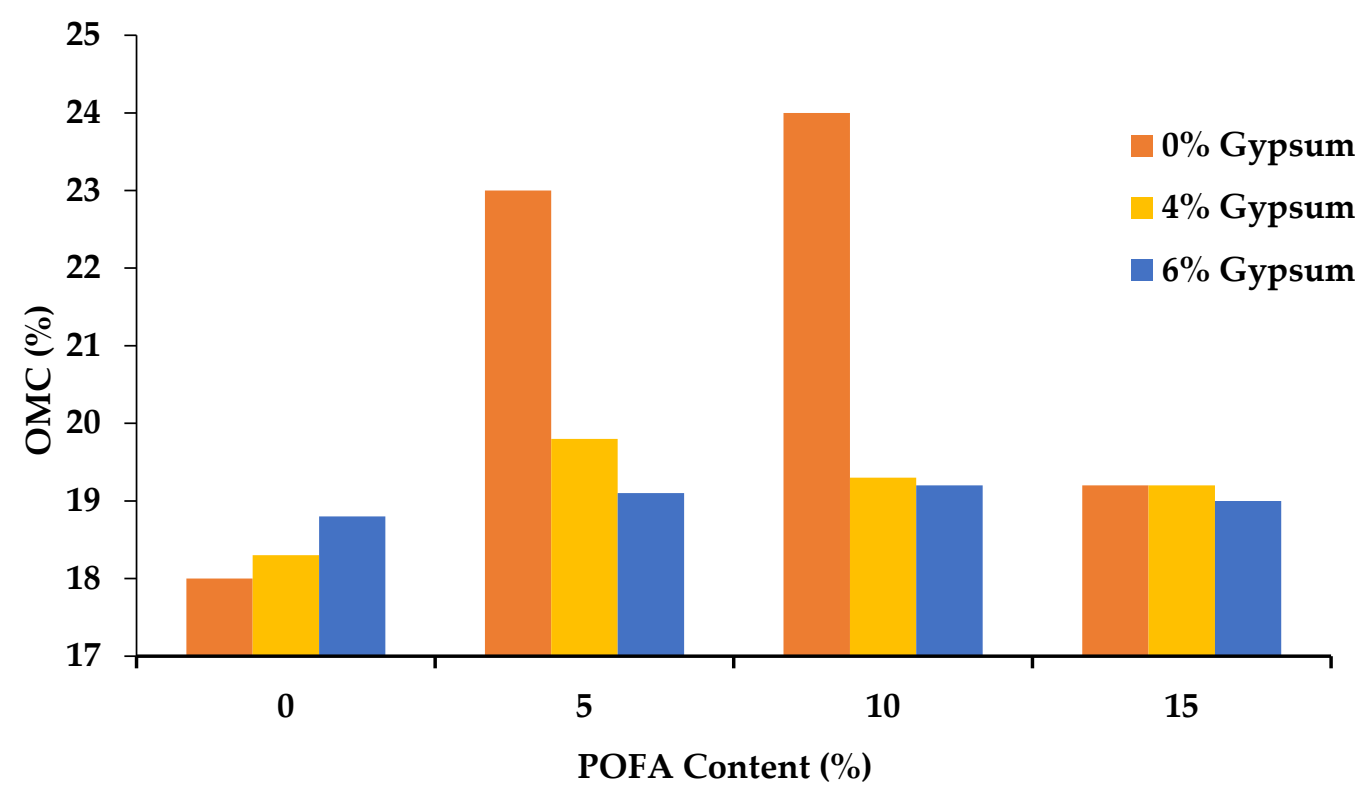

Figure 15. Optimum water content of treated kaolin with various POFA content.

Table 8. Summary of standard deviation and variance of OMC.

\begin{tabular}{cccccc}
\hline Sample & $\begin{array}{c}\text { Standard } \\
\text { Deviation }\end{array}$ & Variance & Sample & $\begin{array}{c}\text { Standard } \\
\text { Deviation }\end{array}$ & Variance \\
\hline K & 0.353 & 0.0199 & K4GP5 & 0.156 & 0.008 \\
KG4 & 1.103 & 0.059 & K4GP10 & 0.509 & 0.026 \\
KG6 & 0.127 & 0.007 & K4GP15 & 0.100 & 0.0052 \\
KP5 & 1.414 & 0.643 & K6GP5 & 0.311 & 0.016 \\
KP10 & 0.495 & 0.021 & K6GP10 & 0.382 & 0.0196 \\
KP15 & 0.127 & 0.0066 & K6GP15 & 0.063 & 0.003 \\
\hline
\end{tabular}

\section{Conclusions}

This research is aimed at improving the properties of processed soft kaolin clay with a combination of POFA and gypsum. POFA and gypsum were separately utilized to treat kaolin to evaluate the singular effect per material. POFA alone exhibited low effectiveness in enhancing soil properties; it is better to be mixed with gypsum. The changes in compressive and shear strength capabilities provided with SEM and EDX can highlight a greater effect of pozzolanic reaction with 0 days, $(24 \mathrm{~h}) 1$ day, 7 days and 28 days of curing. Over the course of the studies carried out, the following main results were obtained:

- In general, kaolin had the highest specific gravity of 2.70 compared to gypsum (2.66) and POFA (2.25). The result also showed a reduction in specific gravity of kaolin when mixed with POFA; however, specific gravity of kaolin is increased when mixed with gypsum, likely due to the type of chemical composition generated and the degree of decomposition or dissolution with water.

- The liquid limit increased with the addition of gypsum and POFA, as they absorb more water. The plastic limit increased due to the sand properties of POFA and gypsum, and thus, the plasticity index marked a clear decrement that can be a sign of the improvement of soil properties when treated with POFA and gypsum. The effect of sandy POFA and gypsum also decreased the linear shrinkage of kaolin.

- The compaction test is considered an important geotechnical indicator in this research, as other tests such as unconfined compression tests and falling head permeability tests 
depend on the results obtained from this test. The result of this test demonstrated an overall increment in optimum water content by adding more POFA and a decrement in maximum dry density, related to the porosity and low specific gravity of POFA as well as the tendency of water absorption by both POFA and gypsum. Meanwhile, the results did not show a remarkable increment in water content when kaolin was mixed with gypsum alone.

Author Contributions: Conceptualization, A.A.-h. and M.H.; Data curation, A.A.-h., M.A., R.F., N.I.V. and S.K.; Formal analysis, A.A.-h., M.H. and M.A.; Funding acquisition, M.H., M.A., R.F., N.I.V. and S.K.; Investigation, A.A.-h. and M.H.; Methodology, A.A.-h.; Project administration, M.H.; Resources, M.A., R.F., N.I.V. and S.K.; Software, R.F. and S.K.; Supervision, M.H.; Validation, A.A.-h., M.H., M.A., R.F., N.I.V. and S.K.; Visualization, M.A. and N.I.V.; Writing-original draft, A.A.-h.; Writing-review and editing, M.H., M.A., R.F., N.I.V. and S.K. All authors have read and agreed to the published version of the manuscript.

Funding: The research was financially supported by Universiti Malaysia Pahang (UMP) and Hokoku Engineering (Japan) through the UMP Matching Grant RDU202701 and Short Term Grant RDU190344, and International Grant UIC201503, respectively. The research is also partially funded by the Ministry of Science and Higher Education of the Russian Federation as part of the World-Class Research Center Program: Advanced Digital Technologies (contract No. 075-15-2020-934 dated 17.11.2020).

Institutional Review Board Statement: Not applicable.

Informed Consent Statement: Not applicable.

Data Availability Statement: Data sharing not applicable.

Acknowledgments: The authors gratefully acknowledge the support given by Universiti Malaysia Pahang (UMP) and Hokoku Engineering (Japan); Deanship of Scientific Research at Prince Sattam bin Abdulaziz University, Alkharj, Saudi Arabia; the Peter the Great Polytechnic University, Saint Petersburg, Russia; and the Department of Civil Engineering, Faculty of Engineering and IT, Amran University, Yemen, for this research.

Conflicts of Interest: The authors declare no conflict of interest.

\section{References}

1. Mohn, D.; Cutright, D.T.J.; Abbas, D.A.; Senko, D.J.M. Impact of Gypsum Bearing Water on Soil Subgrades Stabilized with Lime or Portland Cement. Ph.D. Thesis, The Graduate Faculty of The University of Akron, Akron, OH, USA, 2015.

2. Yilmaz, I.; Civelekoglu, B. Gypsum: An additive for stabilization of swelling clay soils. Appl. Clay Sci. $2009,44,166-172$. [CrossRef]

3. Firoozi, A.A.; Olgun, C.G.; Baghini, M.S. Fundamentals of soil stabilization. Int. J. Geo Eng. 2017, 8, 26. [CrossRef]

4. Little, D.N.; Males, E.H.; Prusinski, J.R.; Stewart, B. Cementitious stabilization. Transp. New Millenn. $2000,1,7$.

5. Sinha, P.; Iyer, K.K.R.R. Effect of Stabilization on Characteristics of Subgrade Soil: A Review, 1st ed.; Fang, H.-Y., Ed.; Springer: Singapore, 2020; Volume 55, ISBN 9789811508868.

6. Sabri, M.M.; Shashkin, K. The mechanical properties of the expandable polyurethane resin based on its volumetric expansion nature. Mag. Civ. Eng. 2020, 6, 9811.

7. Sabri, M.M.; Shashkin, K.G. Improvement of the soil deformation modulus using an expandable polyurethane resin. Mag. Civ. Eng. 2018, 83, 222-234.

8. Sabri, M.M.S.; Shashkin, K.G. Subsoil stabilized by polyurethane resin injection: FEM calculation. Constr. Unique Build. Struct. 2020, 91, 9108 .

9. Dmitrieva, T.; Strokova, V.; Bezrodnykh, A. Influence of the genetic features of soils on the properties of soil-concretes on their basis. Constr. Mater. Prod. 2020, 1, 69-75. [CrossRef]

10. Jafer, H.; Atherton, W.; Sadique, M.; Ruddock, F.; Loffill, E. Development of a new ternary blended cementitious binder produced from waste materials for use in soft soil stabilisation. J. Clean. Prod. 2018, 172, 516-528. [CrossRef]

11. Haridharan, M.; Matheswaran, S.; Murali, G.; Abid, S.R.; Fediuk, R.; Amran, Y.M.; Abdelgader, H.S. Impact response of two-layered grouted aggregate fibrous concrete composite under falling mass impact. Constr. Build. Mater. 2020, $263,120628$. [CrossRef]

12. Kamalrudin, M.; Abdullah, R. Malaysia-moving ahead to sustainable production growth. Malays. Palm Oil Board 2014, 14, 10.

13. Onoja, E.; Chandren, S.; Razak, F.I.A.; Mahat, N.A.; Wahab, R.A. Oil palm (Elaeis guineensis) biomass in Malaysia: The present and future prospects. Waste Biomass Valorization 2018, 10, 2099-2117. [CrossRef] 
14. Aprianti, E. Effect of Curing Condition on the Characteristics of Mortar Containing High Volume Supplementary Cementitious Materials. Ph.D. Thesis, University of Malaya, Kuala Lumpur, Malaysia, 2017.

15. Shafigh, P.; Bin Mahmud, H.; Jumaat, M.Z.; Zargar, M. Agricultural wastes as aggregate in concrete mixtures-A review. Constr. Build. Mater. 2014, 53, 110-117. [CrossRef]

16. Alrshoudi, F.; Mohammadhosseini, H.; Tahir, M.M.; Alyousef, R.; Alghamdi, H.; Alharbi, Y.; Alsaif, A. Drying shrinkage and creep properties of prepacked aggregate concrete reinforced with waste polypropylene fibers. J. Build. Eng. 2020, $32,101522$. [CrossRef]

17. Yusoff, S. Renewable energy from palm oil-Innovation on effective utilization of waste. J. Clean. Prod. 2006, 14, 87-93. [CrossRef]

18. Madurwar, M.V.; Ralegaonkar, R.V.; Mandavgane, S. Application of agro-waste for sustainable construction materials: A review. Constr. Build. Mater. 2013, 38, 872-878. [CrossRef]

19. Abdullah, M.S.; Osman, M.H.; Ahmad, M.F.; Chow, S.H.; Jamalludin, D.; Ahmad, R.; Marajan, C.; Osman, M.H.; Chow, S.H. Performance of palm oil fuel ash (POFA) with lime as stabilising agent for soil improvement. Esteem Acad. J. 2009, 5, 67-78.

20. Hamada, H.M.; Yahaya, F.; Muthusamy, K.; Humada, A. Comparison study between POFA and POCP in terms of chemical composition and physical properties-Review paper. IOP Conf. Ser. Earth Environ. Sci. 2019, 365, 012004. [CrossRef]

21. Hamada, H.M.; Jokhio, G.A.; Yahaya, F.M.; Humada, A.M.; Gul, Y. The present state of the use of palm oil fuel ash (POFA) in concrete. Constr. Build. Mater. 2018, 175, 26-40. [CrossRef]

22. Zeyad, A.M.; Johari, M.A.; Muhamad Bunnori, N.; Ariffin, K.S.; Altwair, N.M. Characteristics of treated palm oil fuel ash and its effects on properties of high strength concrete. Adv. Mater. Res. 2013, 626, 152-156. [CrossRef]

23. Majeed, H.Z.; Taha Jawad, I.; Owaid, H.M.; Jawad, I.T.; Majeed, Z.H.; Owaid, H.M. Fine grained soil stabilization using binary blending of calcium carbide residue and palm oil fuel ash. Int. J. Civ. Eng. Technol. 2018, 9, 939-950.

24. Pourakbar, S.; Asadi, A.; Huat, B.B.; Fasihnikoutalab, M.H. Stabilization of clayey soil using ultrafine palm oil fuel ash (POFA) and cement. Transp. Geotech. 2015, 3, 24-35. [CrossRef]

25. Murthy, G.; Siva Kavya, K.B.V.; Krishna, A.V.; Ganesh, B. Chemical stabilization of sub-grade soil with gypsum and NaCl. Int. J. Adv. Eng. Technol. 2016, 9, 569-581.

26. Mosaberpanah, M.A.; Amran, Y.H.; Akoush, A. Performance investigation of palm kernel shell ash in high strength concrete production. Comput. Concr. 2020, 26, 577-585. [CrossRef]

27. Rahman, Z.; Lee, J.; Rahim, S.; Lihan, T.; Idris, W. Application of gypsum and fly ash as additives in stabilization of tropical peat soil. J. Appl. Sci. 2015, 15, 1006-1012. [CrossRef]

28. Hastuty, I.P. Comparison of the use of cement, gypsum, and limestone on the improvement of clay through unconfined compression Test. J. Civ. Eng. Forum 2019, 5, 131-138. [CrossRef]

29. Iskandar, R.; Hastuty, I.P.; Dianty, W.O. Clay stabilization by using gypsum and paddy husk ash with reference to UCT and CBR value. IOP Conf. Ser. Mater. Sci. Eng. 2018, 309, 012026. [CrossRef]

30. Kuttah, D.; Sato, K. Review on the effect of gypsum content on soil behavior. Transp. Geotech. 2015, 4, 28-37. [CrossRef]

31. Kadhim, S.S.; Huat, B.K. Gypseous Soil Stabilization by Alkaline Activation Method. Ph.D. Thesis, Universiti Putra Malaysia, Selangor, Malaysia, 2017.

32. Kiliç, R.; Küçükali, Ö.; Ulamiş, K. Stabilization of high plasticity clay with lime and gypsum (Ankara, Turkey). Bull. Int. Assoc. Eng. Geol. 2015, 75, 735-744. [CrossRef]

33. Svintsov, A.P.; Shchesnyak, E.L.; Galishnikova, V.V.; Fediuk, R.S.; Stashevskaya, N.A. Effect of nano-modified additives on properties of concrete mixtures during winter season. Constr. Build. Mater. 2020, 237, 117527. [CrossRef]

34. Miller, W.P.; Perkins, H.F.; Radcliffe, D.E.; Sumner, M.E.; Scifres, J.; Kim, J.; Chang, S.C. Use of Gypsum to Improve Physical Properties and Water Relations in Southeastern Soils; Florida Institute of Phosphate Research: Bartow, FL, USA, 1989.

35. Peddaiah, S.; Suresh, K. Experimental study on effect of gypsum and $\mathrm{NaCl}$ in Improvement of engineering properties of clayey soil. Int. J. Eng. Technol. 2017, 9, 2771-2778. [CrossRef]

36. Sikarwar, B.P.S.; Trivedi, M.K. Stabilization of clayey soil by using gypsum and calcium chloride. Int. J. Res. Appl. Sci. Eng. Technol. 2017, 5, 2321-9653.

37. Kolay, P.K.; Pui, M.P. Peat stabilization using gypsum and fly ash. J. Civ. Eng. Sci. Technol. 2010, 1, 1-5. [CrossRef]

38. Murray, H.H.; Kogel, J.E. Engineered clay products for the paper industry. Appl. Clay Sci. 2005, 29, 199-206. [CrossRef]

39. Saeed, K.; Kassim, K.A.; Nur, H. Physicochemical characterization of cement treated kaolin clay. J. Croat. Assoc. Civ. Eng. 2014, 66. [CrossRef]

40. Eisazadeh, A.; Kassim, K.A.; Nur, H. Stabilization of tropical kaolin soil with phosphoric acid and lime. Nat. Hazards 2011, 61, 931-942. [CrossRef]

41. Siddique, R. Coal fly ash. In Waste Materials and by-Products in Concrete; Springer: Berlin, Germany, 2007 ; pp. 177-234.

42. Poernomo, H. Preliminary study of the utilization of the fly ash from coal-fired power plant for immobilization of radioactive waste. Indones. J. Chem. 2011, 11, 258-266. [CrossRef]

43. Bordeian, V.S. Characterisation and Properties of Alkali Activated Pozzolanic Materials. Ph.D. Thesis, Sheffield Hallam University, Sheffield, UK, 2000.

44. British Standards Institution. BSI Methods of Test for Soils for Civil Engineering Purposes_Part 2: Classification Tests (BS 1377-9:1990); British Standards Institution: Milton Keynes, UK, 2020. 
45. Mahowald, K.; Graff, P.; Hartman, J.; Gibson, E. SNAP judgments: A small N acceptability paradigm (SNAP) for linguistic acceptability judgments. Language 2016, 92, 619-635. [CrossRef]

46. Head, K.H. Manual of Soil Laboratory Testing. Soil Classification and Compaction Tests; Pentech Press: London, UK, 1981; Volume 1, p. 43.

47. Kifae, A. Chemical and physical effects on engineering properties of gypseous sub-grade soil. Al Qadisiya J. Eng. Sci. 2010, 3, 18.

48. Kayabali, K. Estimation of liquid, plastic and shrinkage limits using one simple tool. Electron. J. Geotech. Eng. 2012, 17, 2079-2090.

49. Casagrande, A. The structure of clay and its importance in foundation engineering. Bost. Soc. Civ. Eng. J. 1932, 19, 168-209.

50. Al-Swaidani, A.; Hammoud, I.; Meziab, A. Effect of adding natural pozzolana on geotechnical properties of lime-stabilized clayey soil. J. Rock Mech. Geotech. Eng. 2016, 8, 714-725. [CrossRef]

51. Amran, M.; Murali, G.; Fediuk, R.; Vatin, N.; Vasilev, Y.; Abdelgader, H. Palm Oil Fuel Ash-Based Eco-Efficient Concrete: A Critical Review of the Short-Term Properties. Materials 2021, 14, 332. [CrossRef] [PubMed]

52. American Society for Testing and Material. ASTM D698-07 Standard Test Methods for Laboratory Compaction Characteristics of Soil Using Standard Effort; American Society for Testing and Material International: West Conshohocken, PA, USA, 2007; Volume 3, p. 15.

53. Brown, O.R. Potential of Kaolin-Palm Oil Fuel Ash Mixture as Sustainable Landfill Liner Material. Ph.D. Thesis, Universiti Teknologi Malaysia, Johor, Malaysia, 2014.

54. Lesovik, V.S.; Zagorodnyuk, L.K.; Babaev, Z.K.; Dzhumaniyazov, Z.B. Analysis of the causes of brickwork efflorescence in the aral sea region. Glas. Ceram. 2020, 77, 277-279. [CrossRef]

55. Daud, N.N.; Yusoff, Z.; Muhammed, A. Effect of palm oil fuel ash (POFA) content on volumetric shrinkage strain of granite residual soil. In Proceedings of the 5th Brunei International Conference on Engineering and Technology (BICET 2014), Bandar Seri Begawan, Brunei, 1-3 November 2014. [CrossRef]

56. Fediuk, R.S.; Ibragimov, R.A.; Lesovik, V.S.; Pak, A.A.; Krylov, V.V.; Poleschuk, M.M.; Stoyushko, N.Y.; Gladkova, N.A. Processing equipment for grinding of building powders. IOP Conf. Ser. Mater. Sci. Eng. 2018, 327, 042029. [CrossRef]

57. Chernysheva, N.; Lesovik, V.; Fediuk, R.; Vatin, N. Improvement of performances of the gypsum-cement fiber reinforced composite (GCFRC). Materials 2020, 13, 3847. [CrossRef] [PubMed]

58. Sung, C.T.B.; Ishak, C.F.; Abdullah, R.; Othman, R.; Panhwar, Q.A.; Aziz, M.M.A. Soil properties (physical, chemical, biological, mechanical). In Soils of Malaysia; Ashraf, M.A., Othman, R., Ishak, C.F., Eds.; CRC Press: Boca Raton, FL, USA, 2017 ; pp. 103-154.

59. Johari, M.M.; Zeyad, A.; Bunnori, N.M.; Ariffin, K. Engineering and transport properties of high-strength green concrete containing high volume of ultrafine palm oil fuel ash. Constr. Build. Mater. 2012, 30, 281-288. [CrossRef]

60. Ying, K.S.; Awang, H. Performance of aggregate incorporating palm oil fuel ash (POFA) and silt. Int. J. Eng. Adv. Technol. 2019, 9, 1218-1223. [CrossRef]

61. Jafer, H.; Atherton, W.; Sadique, M.; Ruddock, F.; Loffill, E. Stabilisation of soft soil using binary blending of high calcium fly ash and palm oil fuel ash. Appl. Clay Sci. 2018, 152, 323-332. [CrossRef]

62. Kitch, W.A. Geotechnical Engineering Lab Manual with Field Logging Guide; Kendall Hunt Publishing: Dubuque, IA, USA, 2009; ISBN 9781602501690.

63. Geotechnical Engineering Bureau. Test Method for Liquid Limit, Plastic Limit, and Plasticity Index Geotechnical Test Method; Geotechnical Engineering Bureau: New York, NY, USA, 2015.

64. Owhor, S.C.; Ibrahim, A.-A.G. Suitability of using compacted granite residual soil treated with palm oil fuel ASG as hydraulic barrier in municipal landfill. J. Multidiscip. Eng. Sci. Technol. 2018, 5, 9148-9153.

65. Yusof, M.B.B.M.; Brown, O.; Umar, B.A. Estimating optimal combination of palm oil fuel ASH in kaolin as landfill liner using statistical experimental design approach. J. Tek. 2011, 11, 74-86.

66. Lesovik, V.; Voronov, V.; Glagolev, E.; Fediuk, R.; Alaskhanov, A.; Amran, Y.M.; Murali, G.; Baranov, A. Improving the behaviors of foam concrete through the use of composite binder. J. Build. Eng. 2020, 31, 101414. [CrossRef]

67. Daud, N.N.N.; Muhammed, A.S.; Yusoff, Z.M. Geotechnical assessment of palm oil fuel ash (POFA) mixed with granite residual soil for hydraulic barrier purposes. Malays. J. Civ. Eng. 2016, 28, 1-9. [CrossRef]

68. Ahmed, A.; Ugai, K.; Kamei, T. Laboratory and field evaluations of recycled gypsum as a stabilizer agent in embankment construction. Soils Found. 2011, 51, 975-990. [CrossRef]

69. Bhardwaj, K.A. Stabilization of soil with calcium chloride using gypsum. Int. J. Res. Appl. Sci. Eng. Technol. 2019, 7, 117-124. [CrossRef]

70. Piew, S.H.; Shariff, S.M. Effects of POFA and lime on soft soil stabilization. Sci. Int. 2016, 29, 201-205. 